\title{
Teaching Materials English for Informatics based on Multimedia in Manado State Polytechnic
}

\author{
Grace H. Pontoh \\ Departement Of Informatics \\ Manado State Polytechnic
}

\author{
Maya Munaiseche \\ Departement Of Informatics \\ Manado State Polytechnic
}

\author{
Yoice Putung \\ Departement Of Informatics \\ Manado State Polytechnic
}

\begin{abstract}
The purpose of this research is to develop teaching materials to read English for special purposes ESP Informatics Englishbased multimedia in students of informatics at the Department of Electrical Engineering Manado State Polytechnic. This study uses research and development (Research and Development) with stage design, and development of the steps: identification, exploration, realization context, the realization of pedagogical and physical products, while at the stage of evaluation of the measures expert testing and development class, Analysis of measurement data is done by means of qualitative and quantitative. Data on field test results on the effectiveness of the design is processed using a t-test. The measurement results show that an increase in student reading comprehension of the material presented. The results of this study are expected to be used by faculty and students who teach and learn English at Informatics program at the Polytechnic of Manado.
\end{abstract}

\section{Keywords}

Teaching, Materials, English, Informatics

\section{INTRODUCTION}

Teaching material is anything that can be used to facilitate language learning. Teaching materials can be linguistic, visual, audio or kinesthetic, and can be either printed media, tapes, CD-ROM, DVD or the Internet [1].

The teaching materials are: a) print media such as books, workbooks, worksheets or reading material, b) non-print materials such as tapes or audio material, video or computer, c) teaching materials that include either of these sources, namely print media and non- accessible print itself from the internet [2]. Good teaching materials are materials designed on the basis of the principle of 'learner-centered', where learning is focused on the role of students in the classroom as a decision maker ( 'decision making')[3].

The development of teaching materials is a field that studies the principles and procedures of design (model), implementation and evaluation of language teaching materials. This includes production, evaluation and adaptation of language teaching materials used by teachers in the classroom. Teaching materials taken from the ready-made (textbook) or that have been distributed. Ideally there are two aspects, namely the development of interactive teaching materials in explaining the theoretical framework and describes the development and use of teaching materials in the classroom [1].

Teaching materials must be well prepared. Good teaching materials must be in accordance with the needs of the students, the necessary quality of teaching materials should be improved continuously [4]. One of them by utilizing advances in information technology, learning based on multimedia is an educational system that utilizes information technology in teaching and learning [3].

\section{METHOD}

This study uses research and development (Research and Development) model that is in line with procedures developed Brian Tomlinson, namely Design, Development and Evaluation. This research method selected for Tomlinson apply to research the development of second language teaching materials and appropriate steps to research the development of models of teaching materials. Model teaching materials can be used as a suitable model for learning to read English-based on multimedia.

\section{RESULT AND DISCUSION 3.1 The Prosses Of Learning}

The learning process in informatics Study program Electrical Engineering Department of the Polytechnic Manado has 16 times face to face in one semester includes examinations mid semester and semester examinations. English language course syllabus in 16 times face to face covers four language skills, namely reading, writing, listening and speaking. Reading skills (reading) approximately four times face to face. Teachers really have to be smart to choose the topic of reading to fit the needs of students. Therefore, prior to designing materials for teaching English teacher Informatics put through a needs analysis to determine what the actual needs of the teaching materials for students.

Teaching materials read to the students not only to understand the meaning of words and sentence structure alone but students should be able to interpret the content of reading, evaluating and making synthesis, conclusions and applying what is intended in the concept of the teaching materials. In our observation 85 percent of students are very hard to find ideas in teaching materials to read.

\subsection{The Needs Analysis}

To compile teaching materials, which was first performed by the teacher is doing a needs analysis.

The situation analysis now includes information on students, the level of mastery of the target language learners today, and their attitudes towards the target language. Information about students includes educational background. The level of student's mastery to the target language demonstrate their capabilities with respect to the ability of reading and understanding of the vocabulary, grammar and language functions. The attitude of students include their attitudes towards language learning goals.

While the TSA (target situation analysis) is an analysis of the most emphasized to be considered in performing a needs analysis. TSA includes the goals and expectations of students in mastering the English language as well as English language skills required by the industry. Information on the objectives 
and expectations of students can help teachers determine the purpose of the program. In addition, by identifying the necessary English skills the industry, teachers can help learners prepare for the use of English in the workplace.

\subsection{Perception Of Respondent}

Respondents' perceptions of teaching materials, namely respondent faculty and student respondents. Questionnaires were administered to respondents lecturer is about reading English teaching materials, teaching methods and evaluation. Questionnaires were administered to students about the teaching materials, teaching methods and evaluation. All information obtained will be considered to be used in the revision of teaching materials. Figure 1 , shows the result of students responses to the instructional model.

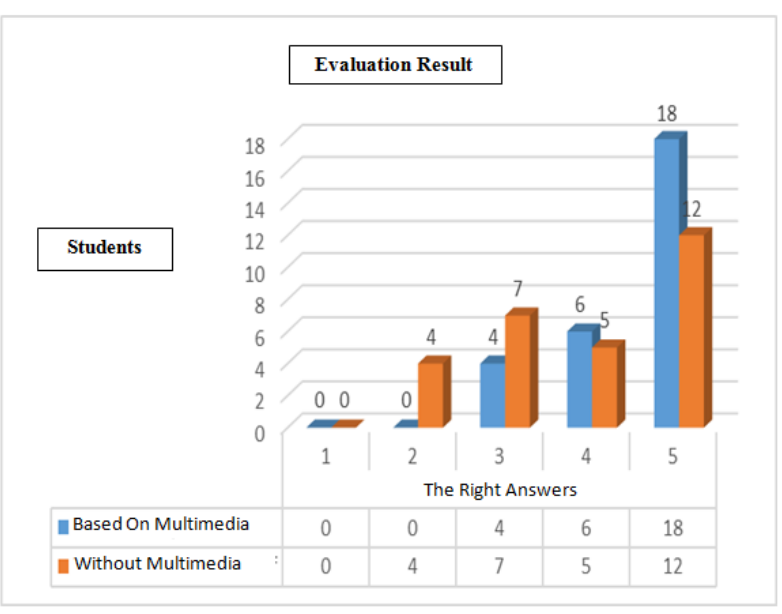

Fig. 1 result of students responses to the instructional model.
From the model of multimedia learning is done in the classroom with the evaluation using t-test results. The two classes of informatics third semester conducted tests in which to grade 3TI1 applied cooperative learning and 3TI2 without method cooperatively with the number of each - each class of 28 students with the material and the same question was obtained difference in the results of the evaluation in which the class applied multimedia learning model has results better achievement.

\section{CONCLUSION}

Based on the results of the study it can be concluded that the development of reading comprehension of English language teaching materials more effectively and efficiently with the applied model of multimedia learning so as to improve English reading comprehension ability, especially students of informatics in the department of electrical engineering, Polytechnic State Of Manado. Teaching materials developed in accordance with the conditions of a student studying in the department of electrical engineering, the evaluation results showed 18 students were able to answer all the questions correctly.

\section{REFERENCES}

[1] Tomlinson, Brian. 2007. Devoloping Materials For Language Teaching. Great Britain: Cromwell Press.

[2] Richard,C.Jack. 2001.Curriculum Development in Language Teaching, USA: Cambridge University Press.

[3] Relly, Jazadi Ed.by.Renandya A.Willy, Methodolgy and Materials Design in Language Teaching, (Singapore: SEAMEO Regional Language Centre: 2003,p.143).

[4] Widodo dan Jasmadi, Panduan Menyusun Bahan Ajar Berbasis Kompetensi (Jakarta: Kompas Gramedia,2008) p.42 